\title{
ENVIRONMENTAL IMPLEMENTATION PLAN - EIP INTRODUCTION
}

by

G. L. Peterson

Westinghouse Savannah River Company

Savannah River Site

Aiken, South Carolina 29808

This paper was prepared in connection with work done under the above contract number with the U.S. Department of Energy. By acceptance of this paper, the publisher and/or recipient acknowledges the U.S. Government's right to retain a nonexclusive, royalty-free license in and to any copyright covering this paper, along with the right to reproduce and to authorize others to reproduce all or part of the copyrighted paper. 


\section{DISCLAIMER}

This report was prepared as an account of work sponsored by an agency of the United States Government. Neither the United States Government nor any agency thereof, nor any of their employees, makes any warranty, express or implied, or assumes any legal liability or responsibility for the accuracy, completeness, or usefulness of any information, apparatus, product, or process disclosed, or represents that its use would not infringe privately owned rights. Reference herein to any specific commercial product, process, or service by trade name, trademark, manufacturer, or otherwise does not necessarily constitute or imply its endorsernent, recommendation, or favoring by the United States Government or any agency thereof. The views and opinions of authors expressed herein do not necessarily state or reflect those of the United States Government or any agency thereof.

This report has been reproduced directly from the best available copy.

Available to DOE and DOE contractors from the Office of Scientific and Technical Information, P. O. Box 62, Oak Ridge, TN 37831; prices available from (615) $576-8401$.

Available to the public from the National Technical Information Service, U. S. Department of Commerce, 5285 Port Royal Rd., Springfield, VA 22161 


\section{Chapter 1}

\section{EIP Introduction}

Chapter was compiled and reviewed by Greg L. Peterson.

\section{CONTENTS}

Site Program Overview

Introduction

Summary

Background

Objectives

Strategy

Implementation

Reflections

Sectional Revision

Integrated Planning

\section{Figures}

1-1. EIP Long-Range Environmental Protection Plan Strategy

1-2. Reflections

Tables

1-1. EIP Revision Schedule 
This page intentionally left blank. 


\section{Site Program Overview}

\section{Introduction}

Due to the commitment and participation of more than 100 professionals from site environniental coordinators, customer improvements and total quality are being incorporated into the Environmental Implementation Plan (EIP). The EIP is now a living document that communicates an overview of site environmental programs and the facility plans that are designed to protect the environment and meet changing regulatory requirements.

Continuous improvement of environmental programs is enhanced through planned quarterly self-assessments during the "Reflections" process. Through the sharing of noteworthy practices, lessons learned, and ideas for improvement, the EIP provides a framework for environmental professionals to promote cost effective solutions and program improvements throug' 'eamwork and communication.

These efforts were initiated by the Central Environmental Committee Executive Committee (CECEC) and developed and coordinated by the EIP subcommittee. The EIP revision process is the baseline for a continuous improvement cycle. Although the EIP is a Westinghouse Savannah River Company (WSRC) document, the environmental-planning process involves and will benefit all site contractors. Together, we are committed to a "Partnership in Environmental Excellence."

\section{Summary}

DOE and the managing contractor, WSRC, are committed to operating SRS in a manner that protects the public health and safety and the environment. This philosophy is contained in DOE Order 5400.1, General Environmental Protection Program, the SRS Strategic Environmental Plan, and in the SRS Mission, Vision, and Principles.

Compliance with environmental regulations and DOE orders relating to environmental protection is an important part of SRS's program. An overview of the strategy to reach our site goal of environmental excellence and compliance with new and existing environmental regulations and DOE orders is found in Chapter Two. Demonstrating environmental excellence is a high priority embodied in DOE and WSRC policy.

SRS is striving constantly to improve its standing as a leader in environmentalprotection activities. DOE-SR, WSRC, and other SRS contractors are committed to environmental excellence and compliance. Managing environmental programs is a major task. More than 1000 people are devoted full-time to environmental activities at SRS. As the environmental laws, regulations, and DOE orders change, SRS environmental professionals work together not only to determine what actions are necessary for compliance, but to determine the most cost-effective actions which will meet or exceed compliance requirements and promote natural-resource protection. 
The EIP is a long-range environmental-protection plan which describes: the strategy for environmental compliance and excellence; site environmental-protection programs; management and support programs; environmental responsibilities; and environmental programs and plans submitted from SRS organizations.

The EIP complies with DOE Order 5400.1 , Chapter III, by providing a long-range environmental-protection plan to give the site the what, when, how, and why for environmental requirements. Through the EIP planning process, which incorporates teamwork and proactive planning, a partnership in environmental excellence is formed.

To comply with DOE Order 5400.1 , the EIP programs identify environmental requircments, program goals for compliance and natural-resource protection, and reference site procedures and guidance documents. Environmental coordinators compare their facility operations against requirements and goals to identify needs. Through communications and teamwork, environmental coordinators establish strategies to meeting the needs, identify activities to implement the strategies, identify needed resources, and develop a schedule to accomplish those activities.

The EIP is written primarily for WSRC management and environmental professionals, but it also will be useful to the DOE-SR and to the environmental coordinators other site contractors. The EIP is designed to complement the environmental planning efforts of DOE-SR and the other site contractors. The EIP publicizes site cnvironmental programs and goals from all SRS organizations to promote a common sitc vision and direction for natural-resource protection and share-savings from costcffective compliance programs to meet regulatory requirements. By including the environmental programs, plans, and responsibilities from all SRS contractors, the EIP provides an holistic view of SRS environmental activities, the inter- and intrarelationships among the environmental media for natural resource protection, and the teamwork by all organizations and environmental committees to achieve our site vision for SRS to be the recognized model for Environmental Excellence in the DOE Nuclear Weapons Complex.

Background

Formal sitewide environmental planning at the SRS began in 1986 with the development and adoption of the Strategic Environmental Plan. The Strategic Environmental Plan describes the philosophy, policy, and overall program direction of environmental programs at SRS. Input into the plan was obtained from a large number of operating contractor personnel, DOE, and the Environmental Advisory Committee. The document contains the following:

- $\quad$ philosophy and policy statements

- key planning assumptions

- visions for the future

- general objectives

- management strategy

- legal requirements

- program strategies for protecting groundwater and soil

- program strategies for protecting surface waters and wetlands 
- program strategies for protecting the atmosphere

- program strategies for managing SRS land and wildlife

The Strategic Environmental Plan provided the basis for the EIP.

The EIP, WSRC-RP-89-453, was issued on August 1, 1989.

The Central Environmental Committee Executive Committee (CECEC) approved formin - an EIP subcommittee in November 1991 to improve and facilitate the EIP revision process. The subcommittee members represent several site organizations. The subcommittee mission is to revise the EIP in a way that solicits and values CEC participation; optimizes the resource requirements for annual revisions; identifies and improves communicating environmental requirements and obligations; publicizes environmental activities, plans, and information; forecasts environmental changes and upcoming regulatory developments; meets or exceeds customers expectations; and combines ideas and perspectives of CEC members and EPD personnel.

A draft revision of the EIP was published in March 1992, which reflects the efforts by site environmental coordinators, CECEC, EPD, SRTC, and the EIP subcommittee.

In September 1992, the EIP Action Plan was developed to incorporate customer improvements and total quality into the EIP revision process.

The March 15, 1993, EIP revision represents the teamwork and commitment to environmental excellence by site environmental coordinators and professionals. 


\section{Objectives}

The objectives to support SRS environmental planning through the EIP are the following:

- meet the long-range environmental-protection plan requirements of DOE Order 5400.1

- improve the communication of environmental requirements, roles and responsibilities, and program goals

- promote common site solutions through teamwork which result in share-savings from cost-effective compliance programs that meet both regulatory requirements and natural-resource protection goals

- forecast environmental needs to promote innovative and cost-effective programs which will meet compliance requirements through applied technology development

- encourage continuous planning and program improvement

- incorporate total quality throughout the EIP planning process

- integrate $E I P$ with other environmental and budgetary plans

- complement environmental planning efforts of DOE-SR and the other site contractors

- meet customer expectations for a practical and useful long-range environmental plan 


\section{Strategy}

The following is strategy for reaching the EIP objectives: (See Figure 1-1)

- forecast five-year program vision and identify milestones to meet the program objectives

- identify and communicate regulatory and other environmental-protection initiatives and requirements

- identify environmental resources (documents, procedures), site environmental responsibilities, and goals of environmental committees

- involve all site organizations in environmental planning to meet site goals and policies

- include the planning information with other SRS organizations (SREL, USFS, WSI) to obtain holistic view of SRS environmental programs

- conduct quarterly "Reflections" to facilitate environmental planning and continuous improvements

- coordinate the EIP revision to incorporate plans consistent with the SRS integrated planning system (Site Development Plan, Mission Plans, Annual Operating Plans)

- revise the EIP individual chapters throughout the year to promote customer involvement to enable a more focused review of individual environmental media programs and their relationship with other environmental media (holistic view)

- request identification of national environmental directions and initiatives by the Environmental Advisory Committee which will promote SRS environmental excellence

- request the Natural Resources Coordinating Committee's assistance to evaluate $E I P$ 's site environmental programs for alignment with natural resource protection goals and to identify mile markers to evaluate SRS progress in achieving naturalresource protection goals

- implement the EIP Action Plan initiatives

- evaluate if customer expectations for EIP are met 
EIP Partnership in Environmental Excellence

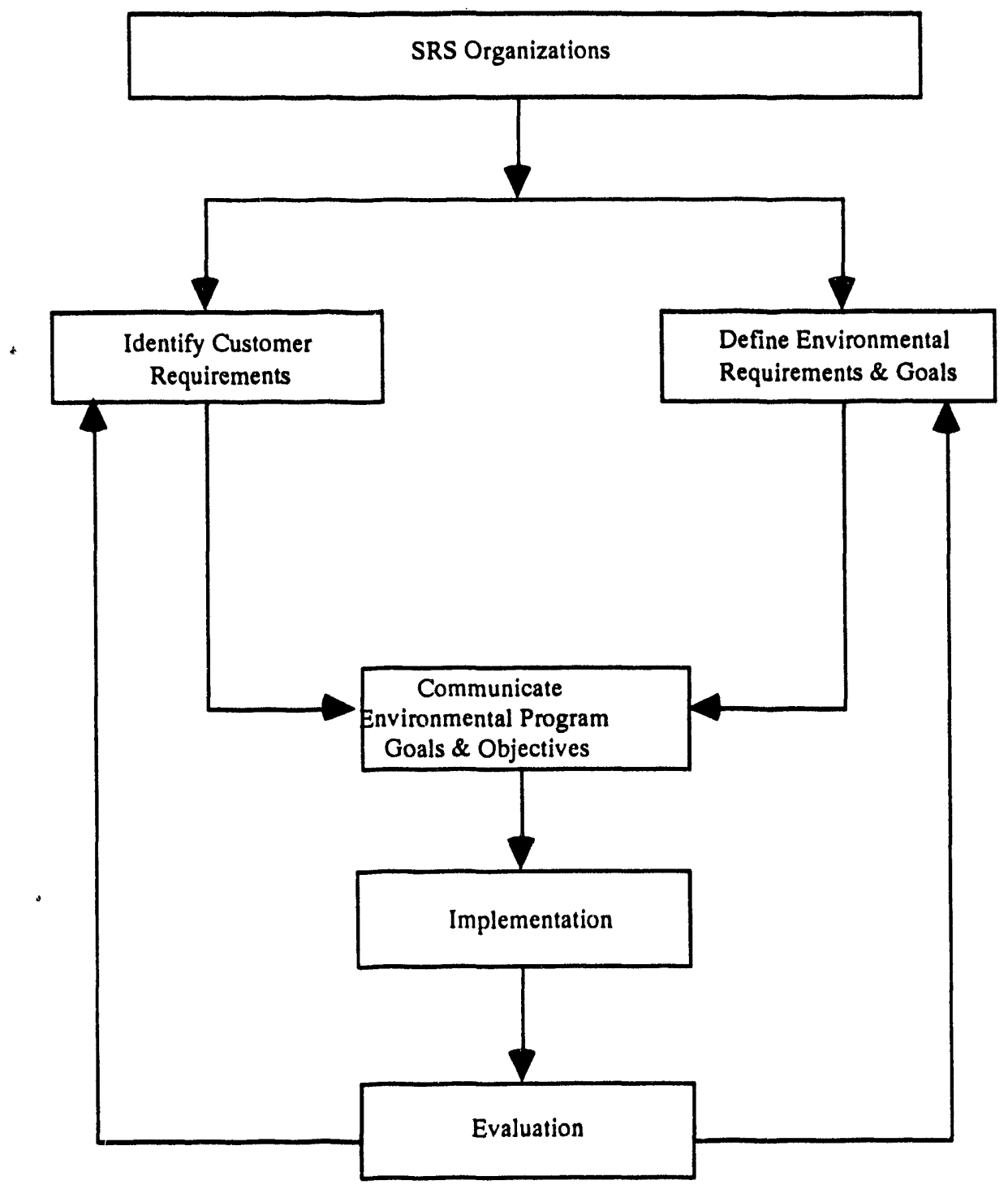

Figure 1-1. EIP Long-Range Environmental Protection Plan Strategy 


\section{Implementation}

Communicating with site organizations, departments, and committees is essential to making the site environmental-planning process work. The EIP planning process gives the site the what, when, how, and why for environmental requirements. Through teamivork and proactive planning, a partnership for environmental excellence is formed to achieve our site vision for SRS to become the recognized model for environmental excellence in the DOE Nuclear Weapons Complex.

Based on this partnership in environmental excellence, the EIP revision process is being improved by customer involvement and communication. The EIP Action Plan submitted by the EIP subcommittee recommends implementing three initiatives (reflections, sectional revision, integrated planning) in order for the EIP to become a continuous planning and improvement process that incorporates total quality and is integrated with other environmental and budgetary plans. The EIP Action Plan is located in Appendix 4 for additional information.

A brief description of each of the three EIP initiatives follows.

\section{Reflections}

\section{Sectional Revision}

Sectional revision will replace the annual revision of the entire EIP by updating different chapters throughout the year (see table 1-1). Each chapter has several implementation programs that will need revision. This change is proposed to lessen the manpower for revision and enable a more concentrated and focused review of individual environmental programs by the environmental coordinators and EPD. This should encourage stake-holder participation and communication in assessing and developing revised goals, strategies, and objectives to meet identified environmental requirements and obligations. This also should improve the overall planning quality through increased program ownership. 
Integrated Planning

Integrated planning is a process that incorporates planning information in the EIP revision into other documents. Programs and projects required to meet environmental compliance goals will need to be integrated into the financial planning documents. Information obtained from EIP environmental program self-assessments during reflections can be integrated into the annual environmental self-assessments. Existing detailed planning and guidance documents will be referenced to prevent duplication and to ensure that the information is accurate.

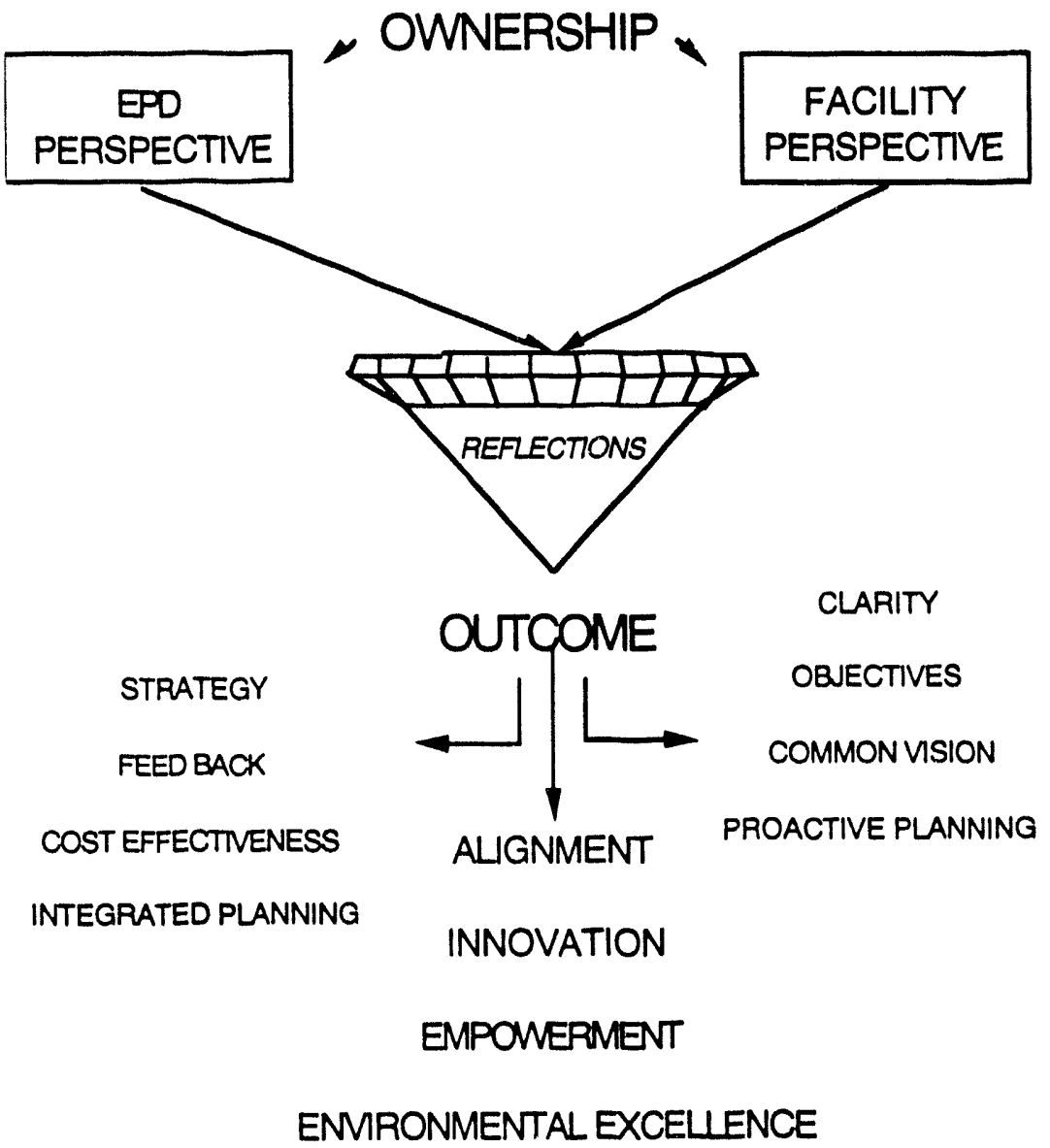

Figure 1.2. Reflections 


\section{Table 1-1. EIP Revision Schedule}

\begin{tabular}{|c|c|}
\hline Month & Chapter \\
\hline January & Waste Management and Disposal \\
\hline January & Environmental Responsibility Summary \\
\hline February & Environmental Restoration \\
\hline February & Natural Resource Protection \\
\hline March & Strategic Plan for Environmental Compliance \\
\hline April & EIP Introduction \\
\hline April & Permitting \\
\hline May & Atmospheric Protection Program \\
\hline May & Site Organizations \\
\hline June & Environmental Compliance Tracking and Data Management \\
\hline July & Employee Education \\
\hline July & Environmental Appraisal and Surveillance Program \\
\hline August & $\begin{array}{l}\text { Chemical Management, Pollution Prevention and Other } \\
\text { Compliance Programs }\end{array}$ \\
\hline September & Quality Assurance Program \\
\hline October & Environmental Monitoring \\
\hline October & Appendix Information \\
\hline November & Executive Summary \\
\hline November & Groundwater Protection \\
\hline November & Division/Department Environmental Summary \\
\hline December & $\begin{array}{l}\text { Emergency Response, Environmental Occurrence Reporting, } \\
\text { and Regulatory Notifications }\end{array}$ \\
\hline Decembe & Environmental Outreach \\
\hline
\end{tabular}


This page intentionally left blank. 

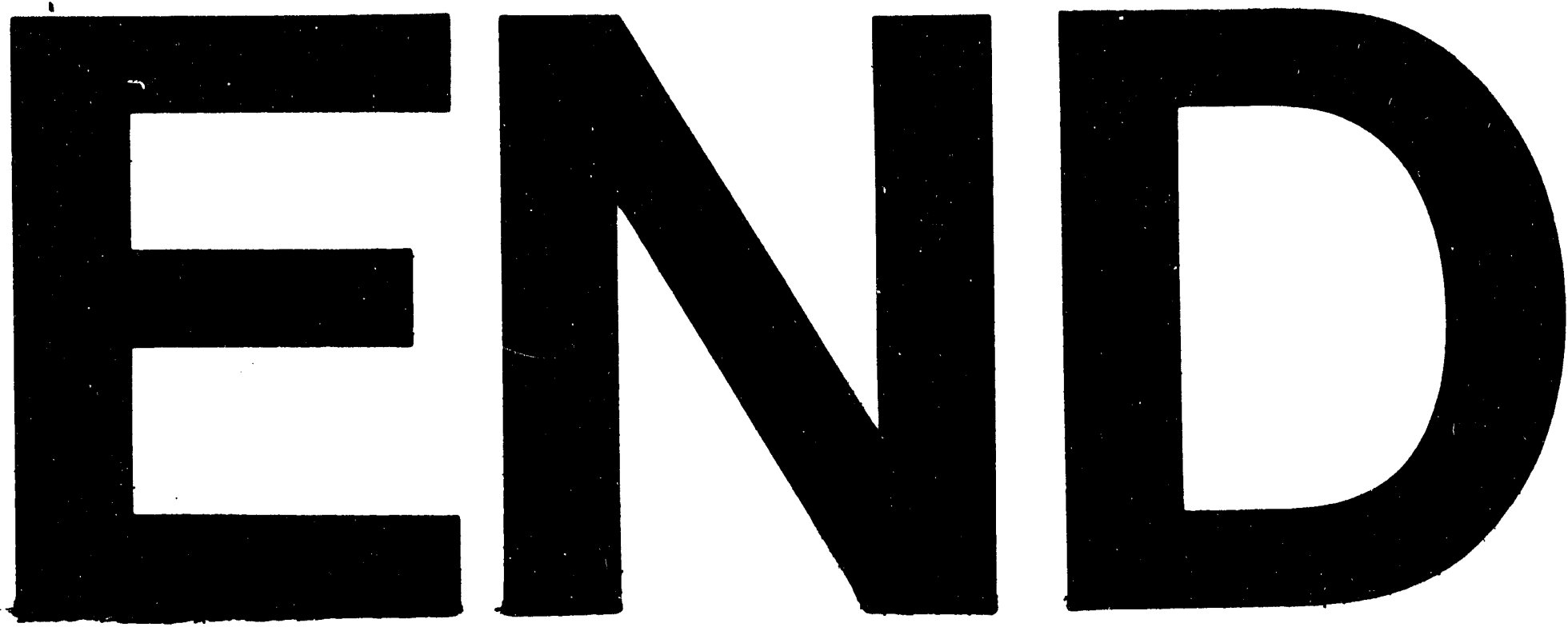

$\infty$
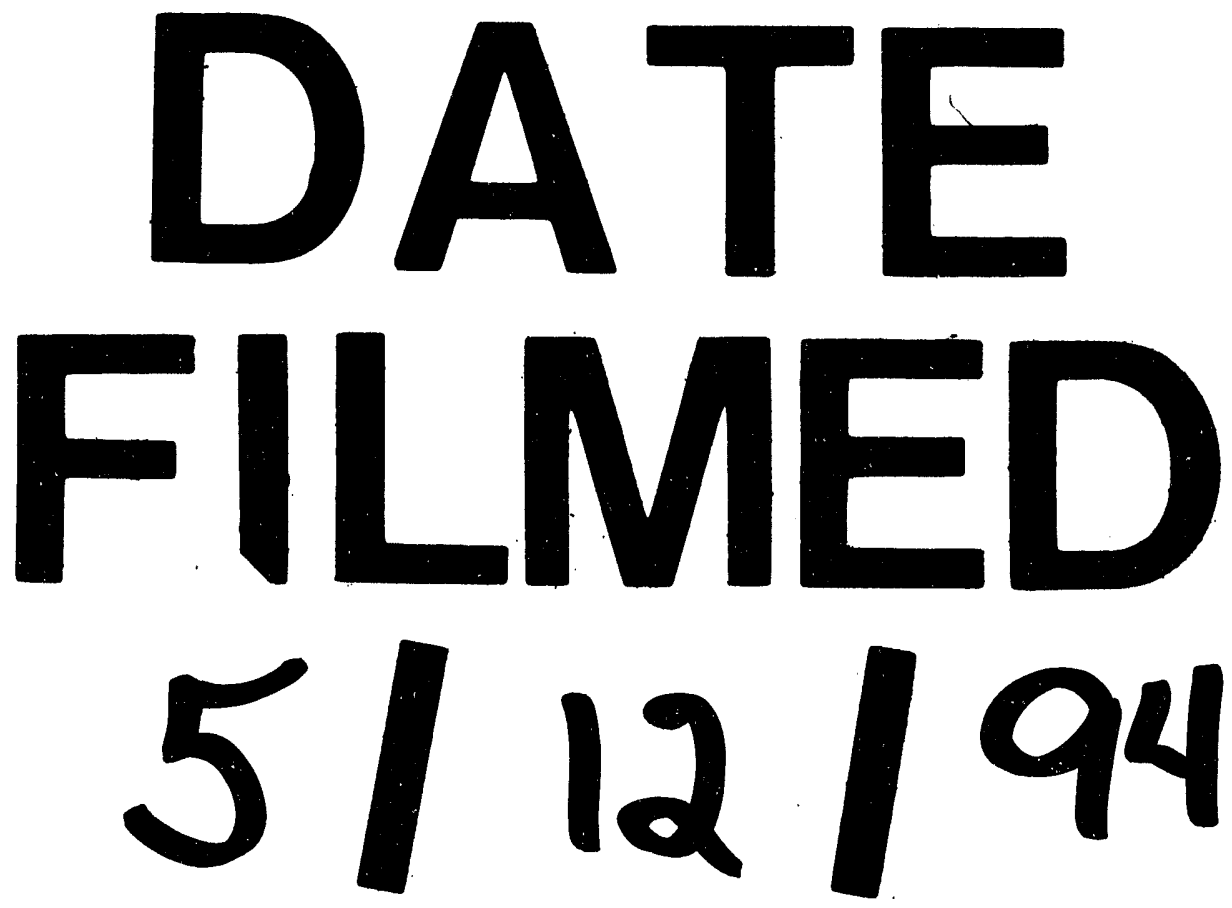

12

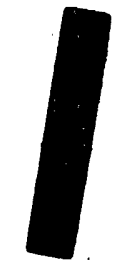

94 
